\title{
Through Eastern Tibet and Kam
}

\section{Author(s): P. K. Kozloff}

Source: The Geographical Journal, Vol. 31, No. 4 (Apr., 1908), pp. 402-415

Published by: geographicalj

Stable URL: http://www.jstor.org/stable/1777845

Accessed: 27-06-2016 04:40 UTC

\section{Your use of the JSTOR archive indicates your acceptance of the Terms \& Conditions of Use, available at}

http://about.jstor.org/terms

JSTOR is a not-for-profit service that helps scholars, researchers, and students discover, use, and build upon a wide range of content in a trusted digital archive. We use information technology and tools to increase productivity and facilitate new forms of scholarship. For more information about JSTOR, please contact support@jstor.org.

The Royal Geographical Society (with the Institute of British Geographers), Wiley are collaborating with JSTOR to digitize, preserve and extend access to The Geographical Journal 
lower layers. The dew effects observed upon the dunes are very remarkable, even when there has been no rain for weeks, and but for the rapid evaporation in the day, one is tempted to think that dew-ponds might be formed, as on the porous chalk downs in England. Such moisture consolidates the lower part of the dune, but, readily evaporating at the surface, allows the top layers to be redistributed by the daily breeze. If strong and continuous winds remove the dry and loose surface too rapidly, erosion forms are produced in the compacted underpart. Thus from several points of view the relation of blown sand to moisture is worth studying.

4. I desire to draw attention to the exaggerated effect of certain storms in transporting sand, and even apparently of holding the finer particles in suspension. This may probably be due to an electrified atmosphere. I have found by experiment that sand, though heavy, is readily and violently moved by electrification, on account, I suppose, of the smallness of the particles. I have not myself gone much further into the interesting but difficult question of the effect of electricity upon the transport of sand. It may be that such winds are responsible in some deserts for much of the transport of sand, whilst the ordinary breezes do most of the modelling of the sand-dunes.

5. The rate of movement of dunes is, of course, interesting, but unfortunately a traveller can seldom deal with it.

Finally, whatever is to be described should be photographed, and the photographs should, whenever possible, be taken in a low morning light--a low light for shadow and relief; the morning, in order to avoid the sandy haze of the later day.

\section{THROUGH EASTERN TIBET AND KAM.}

\section{By Captain P. K. KOZLOFF.*}

INTRODUCTION.

ON Captain P. K. Kozloff's return to Russia in 1901, after his prolonged absence in Tibet, he put the finishing touch to his exploration work by compiling a most valuable scientific report on the lands through which he had passed. The following pages are a translation of that part of his narrative which deals with the expedition's adventures from the time of its leaving the Tsaidam on the journey south. till it reached Chjerku.

During March, 1900, it made its way westwards along the northern bank of the lake Koko-nor, and, crossing the eastern Tsaidam, reached on April 14 the fortified post of the Baron-Dsassak (longitude and latitude $36^{\circ} 10^{\prime} 55^{\prime \prime}$ and $97^{\circ} 21^{\prime} 47^{\prime \prime}$; height, 9380 feet above sea-level). Here a depôt was formed to serve the purpose

* Translated by Captain A. B. Lindsay, 2nd King Edward's Own Gurkha Rifles. In the Geographical Journal, vol. 19, p. 576, is a summary account of this Russian Expedition, 1899-1901, also by Captain Kozloff. 
of a base while in Tibet, and here camel transport was abandoned. The journey onwards is related by Captain Kozloff as follows.*

\section{Narrative.}

With the expedition's arrival at Tsaidam the curtain may be said to have come down on the first act. For a whole year we had lived amongst Mongols-for the most part peaceful and good natured-learning about their country, studying their mode of life, and for transport using camels, an animal which Russians soon became accustomed to on the line of march, especially if commanded by experienced officers. We were compelled to part company with these animals here, and in their stead to possess ourselves of bull yaks, or khainiks. $\dagger$ These beasts live in the mountains and high tablelands of Tibet, where exist nationalities as different in their manners and customs to the primitive Mongols as their fierce and obstinate yaks are to camels.

Savage by nature, the bull yak, when on the line of march, in camp, or when grazing, is always trying to find an opportunity of goring his neighbour, regardless of whether the latter be a bull like himself, a horse, or a human being. The worst characters among them are easily recognizable by the broken points of their horns. Across mountainous country they are slow travellers (from 3 to $3 \frac{1}{2}$ versts an hour, sometimes less), while they carry only half the load of an average-sized camel. As, in addition to this, yaks are more subject to epidemic diseases than camels (plague, khas, $\ddagger$ etc.), they often prove to be a more expensive mode of transport. The difficulties of travelling with them are infinitely greater than when using the far-famed-and deservedly so-" ship of the desert."

As a transport animal, the bull khainik stands considerably higher. It is more gentle ard tractable, more used to narrow footpaths, and to a certain extent is dignified. Consequently it preserves its strength throughout the day's march instead of wasting it when leaving camp, as a yak usually does, by uselessly plunging about from one side of the road to the other. The khainik is, of course, much more valuable, costing about thirty roubles, while a transport yak can generally be bought for ten; that is to say, it is three times as expensive as the yak. A camel caravan can be loaded up more expeditiously than a bull caravan, as the men of the escort, divided into pairs, can work independently, and soon get the caravan ready. This is impossible with bulls. Each animal has to be held by one or two men, while its load has to be lifted up high at the same time $\S$ by at least four, two on either side. The loading of obstinate auimals takes quite five minutes, and requires double the usual number of men, while the baggage suffers in proportion.

Having left the bulky and heavier loads at our Tsaidam depćt, we packed our Tibetan baggage, reduced to the smallest limits, in small boxes, bags, and wallets. The ideal load for a yak is a pair of ammunition boxes weighing, including the felt lining, 5 poods. But even after reducing our allowance to the utmost, we found ourselves with thirty-five loads, to carry which we took forty bulls, the majority of them being khainiks. Besides myself and my immediate assistants, the personnel

* 1 pood $=40 \mathrm{lbs}$; 1 verst $=\frac{2}{3}$ mile approximately $;$ sajen $=7$ feet $; 1$ rouble $=$ 2s. $1 d$. approximately.

† Khainik, a cross between a bull yak and a domestic cow.

$\ddagger$ With khas, yaks lose their appetites, saliva pours out of their mouths, and eventually their hoofs drop off.

§ Camels are loaded up differently. On the word "Tsok tsok" and a gentle pulling of the leading rope, they lie down, and the load need not be lifted high off the ground. 
of the expedition consisted of twelve grenadiers and cossacks, to assist whom in managing the bull transport, to which they were unaccustomed, four local Mongols were engaged at the T'saidam-two, Dadai and Chakdoor, from the village of the Dsun-dsassak, and the other two, Hardy and Jeroy, from the village of the Baron-dsassak. The first of our native companions, Dadai, had previously accompanied Prjevalsky as a guide and Tibetan interpreter, when returning from Lhasa to the Tsaidam on his third journey in Central Asia. In addition to these four Mongols, we commandeered a Chinaman called Li, who knew Tibetan. He was a fine-looking, powerful man, and, when not smoking opium, appeared well able to climb the mountains of Tibet. The Tibetan party was thus brought up to a strength of twenty men.

Besides the above, I also took Ivanoff (who was in charge of our depôt at the Tsaidam) as far as the lakes of the upper Hwang Ho and two selected Mongols to escort bim on the return journey. I did this, feeling certain that, in addition to the boat, he would have to take back a large quantity of skins of mammals and whatever else we might collect, and I therefore took, besides the bulls, three transport camels and three ponies-one for each of them.

Meanwhile the rays of the spring sun were daily becoming more powerful. The shrub and grassy vegetation, coming to life again, beautified the bleak vale of the Tsaidam. In the air, which was fragrant with the aroma of fresh vegetation, the buzzing of insects and the twittering of swallows, soaring high above the mud-walled fort, never ceased for days together. We were all irresistibly attracted to the south, towards the mountains whose dark blue gorges were becoming more clearly visible. In one of those nullahs our Tsaidam hermits -Teleshoff and Afutin, who were in charge of the camels-had for some time past taken up their quarters. In addition to the Mongol shepherd engaged for the period of the depôt's stay at the T'saidam, their paucity in numbers was supplemented by the dogs, which had been our faithful companions from the day of our start from Altaisk. To take the latter's place in the Tibetan caravan, I bought from a neighbouring Mongol a huge Tibetan mastiff called Garza.

By the middle of May we had completed our arrangements for the onward journey, and the 17 th of that pleasant spring month was chosen for our start upon the long and little-known route. By daybreak we were all astir. Loads, bulls, and men filled the courtyard of the fortress, while Russian, Mongolian, and Chinese shouts intermingled to break the morning silence. In addition to those who were setting out, a large crowd of extraneous people had assembled, some of whom worked hard and were useful to us, while others chattered lazily and were a hindrance. The loading up of the bulls was commenced; but how different to dealing with camels! Several of the obstinate brutes lay down; others plunged about, and, having broken away from their attendants, never rested till they had thrown their loads. We spent a long time loading up in that narrow, confined space, and it was not till noon-the very hottest hour of the day-that we were at last able to leave the settlement and wend our way into the open valley. Then we were able to breathe more freely and look around us. After two or three hours' going, the caravan, divided into three sections, was maintaining proper order and moving steadily southwards. Looking back, we all took leave of the village, which seemed to us now so near and dear, and above which could be so clearly seen the meteorological station, as well as the Russian ensign fluttering in the breeze. Muravieff, who was doomed to many days of solitude, was standing on one of the flat roofs watching the fast disappearing column.

Beyond the rugged, flinty waste which rises gradually towards the hills, the Burkhan-Buddha range towers upwards, and in one of its nullahs-Nomokhun by 
PART OF EASTERN TIBET*

Showing routes of Capt.P.K.Kozloff's expedition

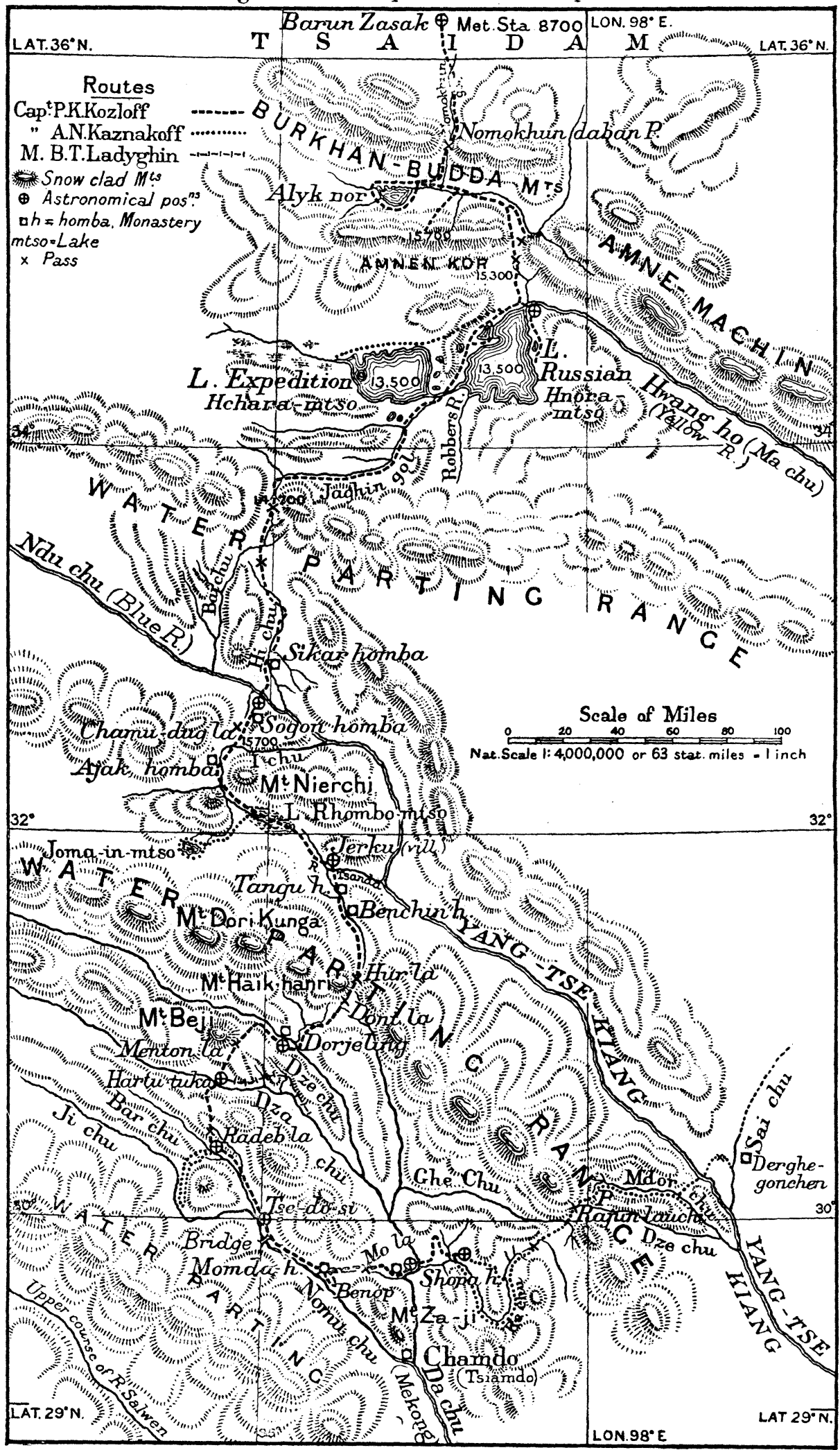

- This map was prepared for Kozloff's summary in vol. 19 of the Jourmal, which

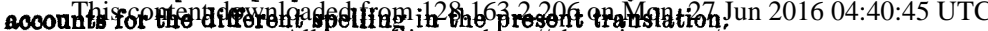
All use subject to http://about.jstor.org/terms 
name-we had arranged to camp. Close to us a small stream wound its way, gathering strength on its onward journey from the bubbling, nurmuring brooks which tumbled into it, and instead of dust and saline deposit, we trod underfoot soft patches of green grass, and began to hear the monotonous cry of the jackdaw, partridge (Caccabis chukar), wild pigeon, and other feathered creatures.

The name Burkhan-Buddha, adopted from the time of Prjevalsky's first journey, is the name given to the comparatively small (in extent) range* bounding the southern end of the eastern Tsaidam. From this shut-in Central Asian basin, these mountains have the appearance of a solid uniform-shaped wall, supporting at a height of 17,000 feet a fairly flat summit (only in places does it reach the line of eternal snows), where the streams rise which tumble down on either side.

The foot of the hills on the northern side is 10,500 feet above the sea, but on the southern side it is nearly 13,500 feet, though measuring scarcely 12 versts from the top. On both sides the nullahs are stony, wild looking, in places very narrow and dark, and, thanks to the scarcity of water, bare and bleak. A few tiny rivulets, on issuing from the hills, bury themselves beneath the surface of the ground, appearing again at the bottom of the nullahs as springs or wells after their subterranean journey. These hills are composed of clear granite, with an admixture of plagioclase, quartz, bisilicate, and epidote ; also of tonalit, gneiss-granite, gneiss, greenstone, limestone with streaks of pyroxene and epidote, calcareous spar, quartz, clay, sandstone, and slate.

In the way of mammals were to be found wild yaks, wild goats or sheep, deer, antelopes, marmots, hare, skunks, foxes, wolves, lynx, panther, and Tibetan bears. And of birds there were white and brown vultures (Gyps himalayensis and Vultur monachus), the lammergeyer (Gypaëtus barbatus), the golden eagle (Aquila daphanea), the hawk (Tinnunculus alaudarius, Hierofalco Hendersoni), owls, brown owls, and occasionally even kites; also the black raven (Corvus corax), the Alpine jackdaw (Fregilus graculus, $F$. Alpinus), wild pigeon (Columba rupestris), two kinds of hill turkey (Tetraogallus thibetanus, T. Kozlowi), wild partridge (Caccabis chukar), mountain finches, jays (Rodoces humilis), blackbirds (Petrocincla saxatilis), Accentor fulvescens, Motacilla, Budytes citreola, Pratincola maura, red-tails, peewits, martins, hill swallows, and many others.

The flowers only begin to bloom in the beginning of summer. On entering the Nomokhun nullah we found, on the narrow patches of green meadowland and amidst the thick brush-like grass, just opening out, yellow dandelions (Leontodon) and two kinds of silverweed (Potentilla anserina). By the banks of the stream were lagotis, and somewhat farther from the water, on the bare, dry, stony soil, termopsis; alongside of this was the tiny Malcolmia, and on the same grassy patches near the rocks, where the full warmth of the sun is felt, grew the beautiful iris.

Some 10 versts higher up the nullah, in small re-entrants, we came across white potentilla, artemisia, androsace, pink draba, and bright vellow, sweet-smelling gadea. Still higher and on damper soil were carex, and growing amongst them the small blue gentiana. In places the ground was yellow with ranunculus and three sorts of iris-two lilac-coloured or blue and one yellow.

During the next day's march, we saw growing in the more tempting side nullahs clumps of very small primula, with pink petals. Here and there amongst these dwarfs towered others, tall and full of sap, with greyish-green leaves and pinky-lilac, sweet-smelling petals. There were various kinds of grasses, more

* In length not more than 100 versts; i.e. from the stream Nomokhun-khoto on the west to the river Egrai-gol on the east. 
ranunculus and polygonum, just in flower. These were along the bottom of the nullah. On the clay hillsides grew three kinds of astragalus, and a tiny euphorbia which literally covered the small mounds of earth thrown up by the burrowing of marmots. We found large quantities of the above flora on the sunny or southwest side, and amongst the rocks was found the first and only specimen of the Rheum spiciforme in flower, as well as the Gnaphalium leontopodium.

Higher in the hills we came across the Przewalskia tangutica, the former handsome iris, pretty yellow pedicularis, ranunculus, two or three saxifraga. The three last, i.e. redicularis, ranunculus, and saxifraga, grew near water. On clay, broken hillsides was the yellow corydalis just coming into flower, alongside of the ephedra and light lilac-coloured astragalus. On soft grassland amongst resplendent primulas was the Adonis coerulea. The great cold coming every now and then had prevented the gentians and violets from flowering earlier. On the southern slope the flowers were poorer and less developed, owing to the colder mountain air; but at the foot of the hills on the southern side, in sheltered places, we found one or two sweetsmelling stocks (Cheiranthus).

We reached the northern foot of the Burkhan-Buddha range the first evening, and on the second the Noyon-bulak (spring), where we had arranged to meet the Baron-dsassak. Here we made our final preparations, and got together a flock of some seventy sheep before proceeding further. After passing some nomad Mongols, the expedition reached an excellent camping-ground, where grazing was plentiful; and here we decided to stay for the best part of a week, so as to learn more about these bills and get better acquainted with our animals. This comparatively long halt was all to the good, as it accustomed our breathing-organs to the rarefied air. For our new companions this was especially necessary, as the weakest of them at this high altitude suffered considerable discomfort for the first few days, after which all went well, and we were able to make numerous excursions to the adjacent uninhabited nullahs. The hill flora daily began more and more to awaken, and consequently to enrich our collection. On reaching the hill Laduigin, our indefatigable botanist, seemed to be rejuvenated, and spent whole days in the nullahs, carefully searching them. Kaznakoff, who was also an expert collector, amused himself getting together a quantity of invertebrate specimens, and seemed thoroughly to enjoy filling jars and bottles with the various kinds of mollusca, beetles, and flies, which were unknown to him, not to mention lizards and snakes. Teleshoff was equally in his element shooting birds and animals peculiar to Tibet. In fact, with our arrival in the hills a mantle of energy seemed to have fallen upon the members of the party, and it was to no vain purpose that the south had so loudly called us from the Tsaidam's inhospitable waste.

We were still obliged to keep our huge, fierce mastiff Garza on the chain, for fear of its attacking the Mongols, including even its former owners. Since it had got to know us it would attack all of them, except those of the Buriats who now and again wore their national costume. The strength of the beast was marvellous. Once when barking excitedly at some intruder it dragged about after it the heavy ammunition-box ( $2 \frac{1}{2}$ poods) to which it had been fastened during the day, pulling it from place to place. At night we used to let it loose, and the Mongols had, in consequence, to be careful where they went.

But, alas! a cloud soon darkened our pleasant pastime in the surrounding hills, in the shape of the serious illness of our Chinese interpreter. With each day he grew thinner and paler, so that, much against my will, I was at last compelled to send him first to the T'saidam, in charge of the Baron-dsassak, and afterwards when convalescent, to his own town-Sining Fu. I discovered later that this invalid ( $\mathrm{Li}$, as the Chinese called him) was a great trouble to the dsassak, 
compelling the latter to produce whatsoever this licentious Chinaman desired to indulge in.

At dawn on May 27-a clear, frosty morning-we recommenced our march, and by nine o'clock had succeeded in crossing the Burkhan-Buddha. The ascent to the pass was steep and stony, and the top covered with a deep layer of snow. The height of the pass-Nomokhun-dawan by name-was, according to my aneroid, 16,030 feet. The neighbouring peaks, towering one above the other amongst the eternal snows, seemed to be thousands of feet higher. The caravan made good time in reaching the summit, with the exception of one of the camels, which we were obliged to lead back and to leave to its own devices on the first patch of flat grazing-ground we could find, till our Mongols should return to the Tsaidam. From the Tsaidam, which was enveloped in a yellowish-grey haze of dust, a piercing wind was blowing, and the temperature was $5 \frac{1}{2}^{\circ}$. Fleecy bits of mist, becoming detached from the remainder, wandered amongst the higher peaks, and turning into black, leaden clouds, every now and again burst into sleet. Towards Tibet the weather looked most forbidding. The sky was overcast, and the dark yellow hilltops, buried in the clouds, had the appearance of being wrapped in cotton-wool. Near the summit no animal life was visible, and such vegetation as grew seemed benumbed with cold. It was only when we descended on the southern side of the range that we came upon a stream, free from ice, whose green banks were a relief to look upon. Here we found quantities of wild-yak bones, and from their enormous size it was evident that the animals were unusually large. We were not fortunate enough to come across any of these beasts, though receut traces of a large herd on the soft clay soil clearly pointed to their frequenting the locality. In the course of the day we saw a bear, as well as a small flock of wild goats or sheep.

The following morning we found it fairly cold at our camp at Shara-beilchir, the thermometer showing the minimum temperature at sunset had been $13.5^{\circ}$ below zero. The stream had dried up, leaving a glistening icy crust behind it, but nevertheless, after an hour or two the rays of the southern sun began to warm us. The onward path lay in a south-westerly direction towards the Alyk-nor lake, which feeds a stream of the same name that flows eastwards till its junction with the Egrai-gol. On climbing the next ridge we saw a large valley, and close to us a wide strip of water shining in the sun. A little later the lake itself came into view, and beyond it, in the grey distance, the Burla-Abgai hills. In the south-east stood out the Amnenkor range of mountains. These, like the Burkhan-Buddha, which we had just crossed, had a covering of snow on the summit. In addition to these principal ranges, there were quantities of smaller hills running away to the south and filling in the whole distance to Tibet, which here had an average height of 13,000 to 15,000 feet.

After a couple of hours we reached the north-east shore of the Alyk-nor, where we selected a soft green patch of ground on which to encamp. Messrs. Kaznakoff and Laduigin, taking advantage of the fine weather on the first day (May 28), went out on the lake in our boat to ascertain its depth. The greatest depth was 15 sajens by the steep bank at the southern end, the shallowest part being off the low bank at the northern end. From the northern shore the lake became gradually deeper for some 7 or 8 versts, and only when within a verst of the southern bank did it suddenly become shallower again.

The men went out to shoot antelopes (Pantholops Hodgsoni and Procapra picticauda), which were to be seen grazing here and there in the wide valley. A herd of wild asses (Asinus kiang) were seen across the stream opposite our camp, and on the other bank of the lake was a large herd of wild yaks. The fabulous quantity of wild mammals to be found everywhere in north-east Tibet can be accounted for by the almost complete absence of their worst enemJ-man. 
Birds, both swimming and wading, soon made their presence on the lake known in the profound silence of the evening. Grey Indian geese, ducks, divers, pintail, redbill, crested mudsuckers (Sterna hirundo), handsome widgeon, egrets, plover (Charagrius Mongolicus), red-legged water-hens (Totanus Calidris), sandpiper (Tringa Temminckii), and black-necked cranes (Grus nigricollis). Close to the shores of the lake or on the stream we found the long-tailed eagle, fish-hawks, falcons, black-eared kites, ravens, larks, jays, finches (Pyrgilauda ruficollis and Onychospiza Taczanowskii), swallows, and a few others.

On the second day of our halt by the Alyk-nor, I set out early in the morning to make a rough sketch of the lake, taking with me Badmajapoff and Badukshanoff, as well as one of the Mongols. We all rode, carrying only what was necessary for a shooting trip on our saddles-a teapot, cups, and a few eatables. The weather was glorious - calm and clear. The sky above was marvellously blue, and we could, thanks to the transparency of the air, make out distinctly the most distant objects in the valley. 'The lowlying shore along which we at first rode was uniform in shape. Sand-banks projected from the water, forming islands, which served as an asylum for the birds. In places we came upon springs, fringed with green, on which wild asses and antelope were feeding. But what interested us most were the bears, whose fresh tracks had been noticeable as soon as we left camp. They had apparently passed the night on the higher ground, moving down at daybreak to the shore along which we were riding. While I was busily employed trying to sketch the banks and put in the shade of colour on the top of the water, as well as to sketch the birds swimming about on it, my companions amused themselves watching the various herds of animals wandering by the shore. The bears were soon sighted, and we could with the naked eye easily distinguish the powerful build of the male compared with smaller dimensions of his mate. Now that they were in our path, the temptation to go after them was irresistible. As we got nearer we saw that they were playing, and that it would consequently be easy to get close enough for a shot at them.

Leaving the ponies, Badmajapoff and I went after them with the cunning of experienced hunters. Not a sound disturbed the deathly stillness of the morning air. Dust, raised by a footfall, fell whence it had risen, and there was no reason to fear that our quarry would scent us. When, however, we reached the patch of level ground on which they were disporting themselves, we were at once rerceived. Bruin instantly stopped playing, and, raising himself on his haunches, looked intently in our direction. His mate shuffled up to him, equally alarmed. For the moment they might have been statues, but quickly arranging which animal each was to take, we tired simultaneously. My bruin fell heavily on the sward, while the she-bear appeared to do the same; but quickly getting up, she almost unzoticeably slipped off the green and disappeared. When we came up to the otherthe dead bear-she had already gone some distance, but with the glasses we could make out her quick shuffling gait and occasional halts, as the poor trightened beast looked back in our direction. My companion mourned her escape, but I endeavoured to console him by saying that in the future months he would have many a chance of correcting his mistake and proving to us his marksmanship.

Having skinned our victin and fastened his coat to one of our saddles, we were ready to move on, when suddenly I caught sight of another large old bear coming quietly towards us from a neighbouring marsh. While I was wondering what was best to be done, he came closer and closer, as if purposely making for us, until he was within 400 paces. Slipping off my pony, I quickly went to meet him, and when within about 120 paces, dropped him like a log with a couple of bullets from my Berdan rifle. His skin, like that of the first, was in excellent condition, so

i.. IV.-APRIL, 1908.] 
we lost no time in removing it. Inside him we found some eggs, probably those of birds whose nests he had pillaged in the marsh. The stomach of the first bruin, which I had killed in the middle of his game of play, had been quite empty.

Having tied the second skin to one of the saddles, we lost no time in pushing on towards the foot of a small hill, Tologinin by name, where by the bank of a clear running stream, flowing from a north-westerly direction into the Alyk-nor, we called a temporary halt. With the dry wood and grass around us, we soon had a nice fire buruing, on which we roasted meat and boiled water for tea. Our appetites that morning were indeed to be envied, for we were as hungry as the proverbial hunter. The ponies we let loose, and they revelled in the green pasture land. The weather was perfectly glorious. Not a cloud was to be seen in the pure blue sky, and the rays of the sun, now high in the heavens, were perceptibly warmer. Lying on my back on the soft velvety grass, I gazed upwards into the wonderfully azure sky, and high above me in the blue I could distinguish wandering birds of pre - vultures-from whose sharp eyes the carcases of our victims had not long escaped. These rovers of the air moved towards the direction of their booty, and then swooped downwards like veritable bombs. Taking up my glasses, I looked at the place where we had left the dead bears, and saw a wild ass come up to one of them, walk round it, and then, stopping with his head erect as if suspecting something, suddenly dash off at full speed. The feathered scavengers were still moving towards one central point-their booty-where a glorious feast awaited them.

After finishing their tea, my companions set to work improving the skins by scraping off the thick fatty tissues, ${ }^{*}$ which, as we threw them aside, served to entice one of the white vultures. It swooped down quite close to us; but for its daring impudence this winged robber forfeited its life, being bowled over by a bullet from one of our military "three-line" rifles. Its plumage was so beautiful that we kept it for our collection. Later we continued our journey round the lake, keeping for as long as possible close to the shore. The western end was much intersected by small streams falling into the lake and forming between them ponds and pools, which made movement both difficult and slow. Avoiding a bog, we got on to what was evidently an animal track, winding about on gravel soll and gradually, almost imperceptibly rising, bringing us on to the high shore of the lake, whence we could see the valley lying before us in all its beauty. On the glistening surface of the water the huge peaks of the Burkhan Buddha were reflected as if in a looking-glass.

Having killed some shore swallows (Cotile riparia) which were flying over the rocky shore, we continued on our way. Shortly afterwards we saw a herd of wild asses coming towards us from the near hills, and they were brave enough to approach within fifty paces of us. I studied them intently through my glasses, but in their large deep eyes could detect no sign of fear-only curiosity. However, we were obliged to push on, and as we moved forward they at once took fright. They raised their heads high, snorted loudly, and then turning round quickly galloped off, kicking at one another as they went. When on the move the wild ass carries his head proudly erect, and waves his short tail from side to side. On our way to camp by the eastern shore of the lake we passed a great number of them, and in addition several antelopes, whose beautiful shape and graceful build, the size and carriage of their horns, as well as their quick and curious gait, called forth remarks of admiration and astonishment from my young companions.

* It is only possible to skin animals roughly when out shooting; the actual cleaning and curing of trophies is done in camp. 
We were so busily occupied in watching the various animals that we imperceptibly approached our camp, to the east of which (and on the left bank of the stream) Ivanoff and some of the cossacks were waiting to show us the best crossing. A few more minutes and we were in. With splendid appetites we tackled the mutton and drank our tea, describing to the others what we had seen and done.

The Alyk-nor lies in an open valley, bounded to the north by the BurkhanBuddha range, and to the south by the Under-Kuku hills. Although nearly 40 versts in circumference, this fresh-water basin seems comparatively small, owing to the gigantic scale of its surroundings-the Tibetan mountains. Its height above the sea is 13,370 feet. Its greatest length, which is by the lowlying shore at the north end, is 15 versts. Its other measurements have been already given. The colour on the top of the water was very variable, depending on the condition of the surface and the light. If the water were calm, the surface smootb, and the sky cloudless, the lake seemed steely-blue. Under opposite conditions its colour was monotonously grey, varied only by occasional dark shades.

As regards ichthyological fauna, the lake could boast of but few varieties, though it was literally crammed with fish. The great quantity of them, as well as in all the lakes, rivers, and streams of T'ibet, is undoubtedly due to these waters having probably never been fished since the beginning of the world. We kept the following specimens from the Alyk-nor for our collection: Schizopygopsis thermalis, Sch. malacanthus and aphua (Nemachilus Kungessanus, N. Crassus), of which, according to Prof. A. M. Inkoylsky, of the Kharkoff University, the latter is a new species.

The foreshores of the lake were covered with a grassy vegetation. The lowlying ground was dotted with green patches, on which were small reeds, blue and yellow iris, primula, and saussurea; and amongst them the common shrubs (Myricaria Prostrata) so typical of Tibet. The flora to be found on the northern shore of the lake were richer and more varied. In a stony nullah close under the hill we came across crimson milk-vetch (Astragalus scythropus), while here and there was sweet-smelling stock (Cheiranthus), and in the narrower clefts under the cliffs were more of the common shrub (Myricaria prostrata). Their leaves appeared paralyzed with the frost, and broke off the moment oue touched them. Amongst them the pedicularis was struggling to come into flower. Near the myricaria, as if thrown there, was the green rose (Saussurea), of which some of the preceding year's tall bushes were still in flower. On the top of the steep cliffs was the corydalis, and lower down the euphorbia. A somewhat less common plant was the Przewalskia tangutica with yellow petals, and growing on the dry clay slopes were wild tea bushes and eurotia.

The stream Alyk-noring-gol, flowing out of the north-east corner of the Alyk-nor, runs in an almost west-to-east direction, corresponding to the trend of the hills and the valley which they enclose. At first narrow and of a yellowish clayey colour, this stream as it moves eastwards widens and becomes clear from the rapid silvery waters of the brooks tumbling into it from the neighbouring Amnen-kor range, which is the western prolongation of the still larger range Amne-machin ("Grey-headed Grandfather"). The length of this stream till its junction with the Egrai-gol (on the left bank) is about 80 versts, and the force of its current was fairly strong.

The Alyk-noring-gol valley, narrowing in places to a width of five versts, and in others opening to nearly double that width, is rich in pasture land, and affords ample grazing for wild animals. The Tsaidam Mongols go there every year to hunt wild asses, antelopes, and wild yaks. The vegetation at the lower end of the valley is little different to that by the lake. The further we proceeded eastwards the greater 
quantities of statice, Przewalskia tangutica, and eurotia were visible; along the streams rising in the Amnen-kor Hyppophæ rhamnoides, Potentilla fruticosa, were abundant. Amongst the yellow and lilac-coloured iris mentioned above was the Iris tigrida, which eventually took its place. This had large beautiful flowers. By the marshy edges of pools we found Ladotis, and a little higher Thermopsis alpina. Here and there was the Myricaria prostrata, but it was more scarce than formerly, and consequently finer. There was also the greenish-yellow slipper, the small lowgrowing ephedra and the Lasiagrostis splendeus; the latter we found along the sides of the valley close to the hills. Amongst the Hyppophre rhamnoides grew clematis (Clematis Orientalis) and the tiny sweet-smelling honeysuckle (Lonicera), and along the branch streams rhubarb (Rheum spiciforme). Under the hill on the southern side of the Burkhan-Buddha range there were quantities of stock (Cheiranthus) with yellow and reddish-brown flowers, deeply rooted amongst the stones. By the marshes along the northern foot of the Amnen-kor various kinds of herbs and other grassy plants were growing, among which was the primula and goldenyellow bachelor's button (Ranunculus).

At the confluence of the Alyk-noring-gol and the Egrai-gol we met for the first time the nomad Tanguts belonging to the Aimak Rangan. They were living in a small number of "banuiks," called by the Tibetans " banags."

After traversing almost the entire length of the Alyk-noring-gol valley, we left it near the Kuku-bulak (spring), entering one of the northern nullahs of the Amnenkor, which we were obliged to cross so as to be able to proceed on our journey south. At first this nullah seemed quite attractive, but as we moved up it the view became wilder, the ascent stonier, steeper, and narrower; even the path was sometimes invisible, and before we had been on it long, Jeroy-one of the Mongols who was invaluable as a shepherd in charge of our animals, though worthless as a guide, for which purpose he had been given to us by Baron dsassak-was, to our disgust, obliged to confess his ignorance as to the road. As soon as I heard this I ordered him to proceed in rear, and trusted to my own instincts and the knowledge which I had acquired in my prolonged wanderings to enable me to guide the party.

The first day of our stay in the Amnen-kor hills, June 6, was remarkable for the great cold, coupled with the quantity of snow which fell in great heavy flakes from early morning till noon, covering the ground with a thick layer more than a foot deep. As we slowly ascended, the feathered inhabitants of the higher hills-mountain finches (Leucosticte hæmatopygia)-flew down the centre of the nullah, and with shrill cries crossed from one side to the other, now and then settling close to the passing caravan. Amidst the noise of their cries I soon heard others-sweet, delicate, soft sounds-quite new to me, and which at once attracted my attention. After a few minutes I was astonished to see on the nearest rocks, as well as on the grass-covered slopes, some very beautiful birds which it was not difficult to recognize as the Leucosticte Roborcwskii, discovered on the late Prjevalsky's last journey in the Burkhan-Buddha mountains, and which I had for some time hoped to come across in this part of the Tibetan hills. M. Prjevalsky's expedition succeeded in securing only one specimen of this bird, in spite of making a special trip in order to try and get a hen bird (they had already got a cock). And here, sixteen years later, I again saw them, both single birds as well as in coveys, amongst which were both the red males and the smaller grey females. At first I only gazed at them longingly from afar, but within half an hour I was holding two dead birds in my hand, and involuntarily I remembered our celtebrated ornithologist V. L. Bianky, who on saying good-bye to me had expressed the hope that I would secure a specimen of this bird, describing the grey colour, which was then more or less a guess. From the specimens in the Zoological Museum of the Imperial 
Academy of Science, the above-mentioned zoologist has been able now to recognize a new species, the Kozlowia (Kozlowia Roborowskii).

Delighted at getting such valuable trophies, I had quite forgotten the unpleasantness of the weather. It was now mid-day. The snow was no longer falling, but the brilliant glare of the glittering snow in the sun hurt our eyes. As the khainiks were tired and our yaks required a rest, we were obliged to halt and ease them for a time of their heavy loads. The neighbouring rocky peaks, towering above the ridge, at times were visible, and again at times were hidden from our view by the moving clouds which wandered picturesquely amongst the mountains. After rather a steep ascent we reached the stony, razor-like ridge. The heavy snow which had fallen, though making movement difficult, enabled us to follow the zigzags, and we at last reached the centre of the pass-height 15,990 feet. The highest peak was some 700 or 1000 feet above it. On neither side of the pass was there any view to be had. To the north it was snowing heavily. To the south was another range of hills. As this route is never used by natives, the path we followed must have been made by animals-wild yaks and asses. The descent down the northern side of this nameless pass was steeper than the ascent, and we were therefore all the sooner at the grassy bottom of the nullah, though obliged to lead each of the bulls so as to prevent them slipping. When darkness came on we decided to bivouac where we were, and we were then able to rest after all the discomforts of the day. We were so worn out that a bear, coming almost into our bivouac like an unexpected guest, was allowed to depart of his own free will. Taking every advantage of his luck, he proceeded along the bottom of the nullah, from bottom to top, and, passing an overhanging rock, leisurely stood up on his hind paws and carefully scratched his back against the rugged projecting boulder.

Next morning, proceeding downwards along the nullah and gradually inclining to the north, we reached a pretty piece of ground surrounded by rocks dotted with shrubs, and close to rich grassland, which enabled us to halt four days with the greatest benefit to our animals. From here two expeditions were made, one by myself to reconnoitre the pass leading over the principal range to the south, the other by Kaznakoff to the north, in order to buy some transport bulls from the nomad Tanguts, and, if possible, to procure a reliable guide. Laduigin and Teleshoff scoured the neighbouring rocks in search of specimens for their collections.

Early on June 9 Kaznakoff and I left camp almost simultaneously. At first I followed the same nullah by which we had arrived, but after a little got into a steeper one leading towards the summit of the southern range. As a rule I preferred riding to walking, and as we went along I carefully scanned the rocks and the grass patches between them for life and flowers. Musk-deer were to be seen grazing, but they scampered off over the rocks as soon as they noticed us. A little further on we saw a herd of wild asses down in the valley, while high above the hills we now and again saw the ubiquitous vultures. The sun rose sluggishly, little by little lighting up the side nullabs, and instead of silvery hoar frost the grass was covered with glittering drops of dew. Hopping about on the boulders were large handsome mountain finches (Pyrhospiza longirostris), Carpodacus rubicilloides, Accentor fulvescens, A. rubeculoides, and other small birds, brightening the summer morning with their songs.

As we neared the pass we came across a red bear, which was so occupied with his own affairs that he never perceived me coming up to him till a couple of bullets laid him low. The sound of the shots echoing loudly among the rocks quickly attracted the vultures, who from the near crags had been watching our movements. My companions on this expedition were Jarkoy and Dadai. Having skinned the bear and tied the trophy to one of the ponies, we were about to proceed on our 
journey when a vulture swooped down so close to me that I had to slay him, his body falling close to that of the bear. As soon as I fired all his winged companions flew up from the rocks, and, circling over the dead bodies, settled again in their former places. But I was surprised to notice that even when we had proceeded some distance they still refrained from approaching the dead bodies. Meanwbile we had neared the pass. The snake-like path wound about the steep slope and crossed on to more accessible ground, where we saw our pretty friends the finches (Kozlowia Roborowskii), and halting for a few moments I shot a couple of them. Another half-hour and we had climbed to the top of the pass, whence we eagerly scanned the broad horizon to the south. In front of us was a typical Tibetan hill, down which the descent was considerably steeper than the ascent which we had just made, and almost in the centre of the panorama before us, glistening amongst the greenish-yellow velvety foothills, lay the watery expanse of the Oring-nor. Beyond this fairly large lake, in the blueish distance, rose the wall-like ridge of snow-capped mountains which give birth to the Yellow and Blue rivers. The rarefied air was remarkably transparent, so much so as to mislead us with regard to the distance of the lake, whose shores we could so clearly see. For long I was unable to tear myself away from this wonderful picture, presenting so striking a contrast to the view on the northern side, where the ground fell away in precipitous wild-looking gorges divided by sharp-ridged spurs.

Being sufficiently satisfied with our knowledge of the road, and after fixing the height of the pass as 15,780 feet, we commenced to retrace our steps along the morning's path, zigzaging about across the narrow strips of snow lying on the northern side of the hill. Soon, on a projecting rock, I saw a second red bear, smaller but similar to that which I had killed earlier in the day. They were evidently a pair, and this was now the widowed female searching for her mate, but she was wise in time, and so avoided following him on his unknown distant journey. On the moist edges of green plots we were again lucky in securing specimens of the mountain finches, which were on this occasion together with the Leucosticte hrmatopygia. Proceeding on to where the dead bruin lay, we found, to our surprise, that the body had not been touched by the vultures, which had now collected in countless numbers. The reason was, doubtless, the presence of the dead bird lying alongside; so to see what would happen, we amused ourselves by removing its body some hundred paces, when we were rewarded by seeing its companions immediately swoop down one after another on to the dead bear and commence their feast.' Fighting over the body, those huge birds attacked each other with beak, talon, and wing, filling the air with their curious discordant cries. To dismount and fire into the brown of them with my "three-line rifle "was the work of a moment, whereupon away they flew, with the exception of six, which had breathed their last. Of the bear little remained. Taking home for our collection a pair of the best specimens of this Gyps himalayensis, we finished our sport for the day, and, as the sun had already sunk below the horizon, we made tracks as quickly as possible for camp.

Kaznakoff had already returned with some nomad Tanguts, from whom he had luckily been able to purchase three transport bulls and some butter. We gave them two of the most tired of our khainiks, which we hoped to be able to pick up again at the Tsaidam on our return journey, and we persuaded one of them, who professed intimate knowledge of the neighbourhood, to accompany us as a guide. In the course of conversation with him regarding the route, I learned that the pass which I had discovered was really one of the best over the Amnen-kor range,*

* Some 10 versts to the east of the pass wbich we crossed is another, called the Kara-gol, which is equally accessible: 
leading into the valley of the Hwang-Ho, or Ma-chu river, as it is called by the Tibetans. It is also known as the Yellow river.

The Amnen-kor range, as has been said above, is the western continuation of the Amne-machin. In length about 100 versts from west to east, and in breadth about 30 versts, this range consists towards the west of two chains of peaks, towering among the eternal snows. We determined the level of the snow-line here as about 16,170 feet above the sea. From the Tibetan side we only were able to see these lofty snow-capped peaks on the western half of the above range. Generally speaking, the Amnen-kor appears much less imposing from the south than from the north. The northern slopes of the Amnen-kor, being usually under snow, feed a number of small streams belonging to the Tsaidam basin. The southern side gives rise to one or two, whose waters fall into the Hwang-Ho, which itself runs into the Pacific ocean. With regard to the indefinite expression "one or two," I should mention that one stream was reconnoitred by us, and is accordingly shown on the map. It rises in the western and higher part of the Amnen-kor, and, en route to the Yellow river, receives on its left bank several streams, which flow from the nullahs further east. As the eastern portion of the Amnen-kor is still unknown, one can only guess as to the existence of other streams. The flora and fauna of this range are, generally speaking, much the same as those on the more northern portion of the Burkhan-Buddha.

( $T$ o be continued.)

\section{EXPERIMENTS ON THE TRANSPORTING POWER OF SEA CURRENTS.*}

\section{By Dr. JOHN S. OWENS.}

THE great differences of opinion which exist as to the relative importance of wave and current action in moving material upon the foreshore or sea-bed show the necessity for some experimental investigation of the subject. It is one of great importance in connection with the study of coast erosion, and, furthermore, it is one which is beset with many difficulties and pitfalls.

The experiments about to be described, while only touching the fringe of the subject, will, I hope, give rise to some discussion from which valuable information may be obtained; and as the matter is one pre-eminently suited for research, the opinion of the members upon the lines along which this should run will be valuable. These experiments were made last August, on the coast of the Wash, near Holme, Norfolk, where there is a fine stretch of sands exposed at low water; and, owing to the existence of several large pools or swills left by the receding tide, currents of varying velocities could be obtained near the outlets of these pools into the sea. I wished, in the first place, to find out, by actual trial on a natural bed, what sized stones a current of a certain velocity could move.

The method adopted was as follows: Having procured and numbered a series of flint stones ranging in size from half an inch to 6 inches in diameter, I found a suitable current, and placed these stones one by one on the bottom over which the current was flowing, until the size was found which the current was just able to move, the next size above being refused ; the number of the stone was then noted. The next step was to measure the velocity of the current. This was done by driving two stakes into the bed a measured distance apart, and timing the travel of a float

* Research Department, November 15, 1907. 